ESSAYS IN COOPERATIVE GAMES 


\section{THEORY AND DECISION LIBRARY}

\section{General Editors: W. Leinfellner (Vienna) and G. Eberlein (Munich)}

Series A: Philosophy and Methodology of the Social Sciences

Series B: Mathematical and Statistical Methods

Series C: Game Theory, Mathematical Programming and Operations Research

Series D: System Theory, Knowledge Engineering an Problem Solving

\section{SERIES C: GAME THEORY, MATHEMATICAL PROGRAMMING AND OPERATIONS RESEARCH}

VOLUME 36

Editor-in Chief: H. Peters (Maastricht University); Honorary Editor: S.H. Tijs (Tilburg): Editorial Board: E.E.C. van Damme (Tilburg), H. Keiding (Copenhagen), J.-F. Mertens (Louvainla-Neuve), H. Moulin (Rice University), S. Muto (Tokyo University), T. Parthasarathy (New Delhi), B. Peleg (Jerusalem), T. E. S. Raghavan (Chicago), J. Rosenmüller (Bielefeld), A. Roth (Pittsburgh), D. Schmeidler (Tel-Aviv), R. Selten (Bonn), W. Thomson (Rochester, NY).

Scope: Particular attention is paid in this series to game theory and operations research, their formal aspects and their applications to economic, political and social sciences as well as to socio-biology. It will encourage high standards in the application of game-theoretical methods to individual and social decision making. 


\title{
ESSAYS IN COOPERATIVE GAMES
}

In Honor of Guillermo Owen

\author{
Edited by \\ GIANFRANCO GAMBARELLI
}

University of Bergamo, Italy 
A C.I.P. Catalogue record for this book is available from the Library of Congress.

Printed on acid-free paper

ISBN 978-1-4419-5260-8 ISBN 978-1-4020-2936-3 (eBook)

DOI 10.1007/978-1-4020-2936-3

All Right Reserved

(C) 2004 Springer Science+Business Media New York

Originally published by Kluwer Academic Publishers, Boston in 2004

Softcover reprint of the hardcover 1st edition 2004

No part of this work may be reproduced, stored in a retrieval system, or transmitted in any form or by any means, electronic, mechanical, photocopying, microfilming, recording or otherwise, without written permission from the Publisher, with the exception of any material supplied specifically for the purpose of being entered and executed on a computer system, for exclusive use by the purchaser of the work. 


\section{Table of Contents}

1. Foreword vii

2. Acknowledgements viii

3. A Short Biography of Guillermo Owen ix $-\mathrm{x}$

The Dawnings

4. The Coming of Game Theory - Gianfranco Gambarelli and Guillermo Owen

5. Guillermo Owen's Proof of the Minimax Theorem Ken Binmore

Coalition Formation

6. Encouraging a Coalition Formation - Michael Maschler

Values

7. A Comparison of Non-Transferable Utility Values Sergiu Hart

8. The $P$-Value for Cost Sharing in Minimum Cost Spanning Tree Situations - Rodica Branzei, Stefano Moretti, Henk Norde and Stef Tijs

9. A Unified Approach to the Myerson Value and the Position Value - Daniel Gómez, Enrique GonzálezArangüena, Conrado Manuel, Guillermo Owen and Monica Del Pozo

Power Indices

10. $\alpha$-Decisiveness in Simple Games - Francesc Carreras

11. Monotonicity of Power and Power Measures Manfred J. Holler and Stefan Napel 
12. On the Meaning of Owen-Banzhaf Coalitional Value in Voting Situations - Annick Laruelle and Federico Valenciano

13. "Counting" Power Indices for Games with a Priori Unions - Marcin Malawski

Dynamic Games

14. The Dynamic Stability of Coalitionist Behaviour for Two-Strategy Bimatrix Games - Ross Cressman, József Garay, Antonino Scarelli and Zoltán Varga

15. Dynamic Coalition Formation in the Apex Game Emiko Fukuda and Shigeo Muto

16. How Many People Can be Controlled in a Group Pursuit Game - Yaroslavna Pankratova and Svetlana Tarashnina

Applications

17. Relevance of Winning Coalitions in Indirect Control of Corporations - Enrico Denti and Nando Prati

18. Takeover Prices and Portfolio Theory - Gianfranco Gambarelli and Serena Pesce

19. A Note on the Owen Set of Linear Programming Games and Nash Equilibria - Vito Fragnelli

20. On the Owen Set of Transportation Situations Natividad Llorca, Elisenda Molina, Manuel Pulido and Joaquin Sánchez-Soriano

21. The Lovász Extension of Market Games - Encarnación Algaba, Jesús M. Bilbao, Julio R. Fernández and Andres Jiménez 


\section{FOREWORD}

This special issue of Theory and Decision contains a brief history of early Game Theory and collates selected contributions on Game Theory which develop Guillermo Owen's own results. All contributions (except for the first on Minimax Theorem) regard Cooperative Games, of which Owen is undoubtedly a leader. The papers cover both theoretical aspects (Coalition Formation, Values, Simple Games and Dynamic Games) and applied aspects (in Finance, Production, Transportation and Market Games).

These works were written in honour of Guillermo Owen on the occasion of his 65th birthday by authors who participated in the XVth Italian Meeting on Game Theory and Applications, organized by Gian Italo Bischi in Urbino, 9-12 July 2003. 
viii

\section{ACKNOWLEDGEMENTS}

I would like to extend my thanks to Guillermo Owen, whose invaluable scientific research formed the basis for this special issue, to Gian Italo Bischi, for his fundamental organizational skills and to all participants at the Meeting who provided the authors with extremely useful comments which helped to improve their contributions. Special thanks to all the experts whose invaluable work in selecting and advice contributed towards making this special issue scientifically sound: Elettra Agliardi, Tamer Basar, Mike Ball, Jesus Mario Bilbao, Steven J. Brams, Dan Fensenthal, Vito Fragnelli, Daniel Gomez, Manfred Holler, Harvo Imai, Rida Laraki, Annick Laruelle, Ehud Lehrer, Moshe Machover, Lina Mallozzi, Jacek Mercik, Dunia Milanesi, Maria Montero, Hannu Nurmi, Francesco Passarelli, Fioravante Patrone, Manuel A. Pulido, Andrea Resti, Joachim Rosenmuller, Agnieszka Rusinowska, Martha Saboyà, Pier Luigi Sacco, Marco Slikker, Stef Tijs, Amparo Urbano, Federico Valenciano, Zoltán Varga, Roy Weintraub, David Wettstein.

I would also like to thank Herma Drees, Arianna Rencurosi and Elena Vorobieva for their technical help, and Marie Sheldon for all her help with the editorial work. Very special thanks go to Cathelijne van Herwaarden for her advice, encouragement and assistance. Finally, I would like to give a heartfelt mention to Ms. Henriëtte Antoinette Beckand Verwée (also known as Nenne). 


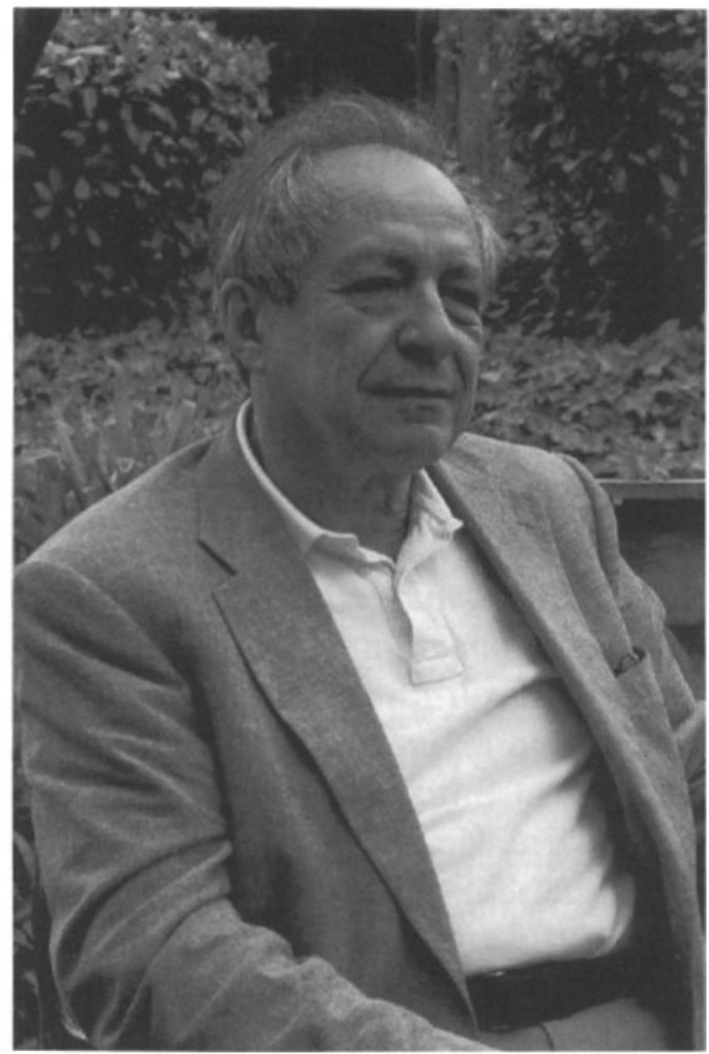

Guillermo Owen

\section{A SHORT BIOGRAPHY OF GUILLERMO OWEN}

Guillermo Owen is considered to be one of the "founding fathers" of Game Theory both for his volume Game Theory and his contributions to the research at a theoretical and an applicative level. His volume Game Theory, published by Academic Press $(1967,1982,1995)$ has constituted the "Gutenberg phase" of Game Theory because of its many translations into German, Japanese, Russian, Polish, and Rumanian. His theoretical contributions have been especially expanded on Economic Equilibrium, Multilinear Extensions, Voting and Not-Atomic Games. His applicative contributions 
have been particularly regarded on Finance, Politics, Economics and studies on Environment, Conflicts and Terrorism.

He was born in Bogotà (Colombia) on 4th May 1938. He moved to Lausanne (Switzerland) where he obtained a diploma at the Lycee Jaccard. In 1957 he moved to Princeton, where he obtained a B.S. a year later. In 1962 he obtained a Ph.D. in Mathematics, with a thesis on Game Theory supervised by Harold Kuhn. His first work experience was carried out at Fordham University (New York), Rice University (Houston, TX) and the University of the Andes (Bogotà). He subsequently started publishing in various scientific reviews, of whose editorial boards he later joined: International Journal of Game Theory, Games and Economic Behaviour, Management Science, Revista Española de Economia, and several others. He is now a member of many scientific communities: the (Colombian) Academy of Physical and Exact Sciences, the Royal Academy of Arts and Sciences of Barcelona (Spain) and the Third World Academy of Sciences. He is at present a full professor of mathematics for the U.S. Navy at the Naval Postgraduate School in Monterey (California), where he has been working for the last 20 years and has been Faculty Chair for 10 years. 